Vol 13, Issue 6, 2020

\title{
ASSOCIATION OF SERUM SIALIC ACID AND SERUM URIC ACID LEVELS WITH FASTING BLOOD GLUCOSE LEVELS IN TYPE-2 DIABETES MELLITUS PATIENTS
}

\author{
YENDREMBAM PASCAL SINGH ${ }^{1}$, VED PAL SINGH PUNIA ${ }^{2}$, GLADYS RAI ${ }^{3}$, MANOJ KUMAR NANDKEOLIAR ${ }^{4 *}$ \\ ${ }^{1}$ Department of Biochemistry, School of Medical Sciences and Research and Sharda Hospital, Sharda University, Greater Noida, \\ Uttar Pradesh, India. ${ }^{2}$ Department of Medicine, School of Medical Sciences and Research and Sharda Hospital, Sharda University, \\ Greater Noida, Uttar Pradesh, India. ${ }^{3}$ Department of Biochemistry, School of Medical Sciences and Research and Sharda Hospital, \\ Sharda University, Greater Noida, Uttar Pradesh, India. ${ }^{4}$ Department of Biochemistry, School of Medical Sciences and Research and \\ Sharda Hospital, Sharda University, Greater Noida, Uttar Pradesh, India. Email: drmanojkumar55@gmail.com
}

Received: 05 March 2020, Revised and Accepted: 07 April 2020

ABSTRACT

Objectives: The objective of the study was to estimate the serum sialic acid and serum uric acid levels in patients with type-2 diabetes mellitus and non-diabetic individuals and determining the association of serum sialic acid and serum uric acid levels with fasting blood glucose levels in patients with type- 2 diabetes mellitus and also in non-diabetic individuals.

Methods: The study was a cross-sectional analysis where 70 individuals in the age group of 30-70 years participated during 6 months period. This included two groups, one for type-2 diabetes patients as cases and other non-diabetics as controls. In each group, 35 individuals participated. There were 15 males and 20 females in type- 2 diabetic group and 16 males and 19 females in non-diabetic group. Fasting blood glucose, serum sialic acid, and serum uric acid were estimated in both the groups.

Results: In this study, the serum sialic acid levels of type- 2 diabetes mellitus were shown to be increased (76.60 \pm 7.89 ) when compared to nondiabetics (39.66 \pm 9.55 ) with a statistically significant, $\mathrm{p}<0.001$. The serum uric acid concentrations were also found to be slightly elevated in type- 2 diabetes mellitus ( $4.48 \pm 0.79)$ when compared to non-diabetics $(4.28 \pm 0.89)$ with a statistically non-significant, $p=0.323$

Conclusion: Based on this study, it is concluded that serum sialic acid and serum uric acid levels have been found to be positively associated with type2 diabetes mellitus in both men and women, indicating the risk of developing microvascular complications in those patients. Therefore, estimating the sialic acid and uric acid levels can aid in the early diagnosis and prevention of microvascular complications caused by type- 2 diabetes mellitus.

Keywords: Sialic acid, Uric acid, Type-2 Diabetes Mellitus, Microvascular complication.

(C) 2020 The Authors. Published by Innovare Academic Sciences Pvt Ltd. This is an open access article under the CC BY license (http://creativecommons. org/licenses/by/4. 0/) DOI: http://dx.doi.org/10.22159/ajpcr.2020.v13i6.37349

\section{INTRODUCTION}

Diabetes mellitus is one of the chronic metabolic syndromes characterized by increased levels of blood glucose that affect carbohydrate metabolism due to insulin deficiency or because of the factors that hinder insulin action [1] and it is related to long-term damage to multiple organs [2]. It is one of the chronic diseases most widely experienced in the world and has more than doubled the number of adults with diabetes over the past three decades [3]. Type2 diabetes mellitus accounts for $90-95 \%$ of all cases of diabetes that is characterized by chronic hyperglycemia, leading to multiple organ systems failure, which, in turn, increases morbidity and mortality [4]. Due to persistent hyperglycemia and inadequate diabetes regulation, some risks occur. These include microvascular disorders such as retinopathy, nephropathy, and neuropathy [5]. A correlation has been suggested in many of the prospective studies between specific inflammatory markers and type- 2 diabetes mellitus, and it is also believed that inflammation contributes to the progression of type- 2 diabetes mellitus [6].

Sialic acid is among the markers for inflammation of the acute-phase response [7]. It is a family of derivatives of acetylated neuraminic acid which make up an important component of glycoproteins and glycolipids [8]. Many of these glycoproteins have sialic acid as the end sugar in their chain of oligosaccharide [9]. It functions as a cofactor of many cell receptors and is correlated positively with most acutephase reactants [8]. Serum sialic acid concentration in type-2 diabetes mellitus is often found to be significantly increased and it is associated with microvascular complications as reported in some prospective studies $[10,11]$

The final product of purine metabolism is uric acid. Hypoxanthine and xanthine are oxidized to uric acid through xanthine oxidase. As its byproduct, it generates $\mathrm{O}_{2}$ and $\mathrm{H}_{2} \mathrm{O}_{2}$. Hyperuricemia may be strongly linked to an insulin resistance syndrome which is a type-2 diabetes risk factor [12]. Recent studies have also found the serum uric acid to be type2 diabetes risk factor [13]. A positive correlation between high serum uric acid and diabetes mellitus has been documented in some studies [14-19] while there was no association [20] or inverse relationship in some other studies [21,22]. Hence, the relationship between the levels of serum uric acid and diabetes mellitus has not yet been clear.

Our research, therefore, aimed to examine the association of serum sialic acid and serum uric acid with fasting blood glucose levels in diabetics and non-diabetics individuals.

\section{METHODS}

Seventy individuals in the age group of 30-70 years during the 6 months period participated in this study. This included two groups, one for type- 2 diabetes patients as cases and other non-diabetics as controls. In each group, 35 individuals participated. There were 15 males and 20 females in type- 2 diabetic group and 16 males and 19 females in non-diabetic group. 


\section{Inclusion criteria}

This study has recruited all newly diagnosed or already diagnosed type- 2 diabetes mellitus patients taking oral hypoglycemic medication. A fasting blood glucose level of $126 \mathrm{mg} / \mathrm{dl}$ or higher was taken, based on the diagnostic criteria of the American Diabetes Association [23].

\section{Exclusion criteria}

Excluded criteria from this study were cases of type-2 diabetes mellitus that was associated with acute and chronic inflammatory disorders, obesity, pregnancy, pre-existing kidney diseases, gout, medications influencing uric acid levels, HIV/AIDS medicines. and thyroid disorders.

Blood collection, separation, storage, and analysis of sample After overnight fasting, $2 \mathrm{ml}$ of venous blood sample was collected using all aseptic precaution in plain Vacutainer for the assessment of serum sialic acid and serum uric acid and $1 \mathrm{ml}$ blood sample was collected in fluoride Vacutainer for the estimation of fasting blood glucose. The plain Vacutainer was centrifuged at 3000 r.p.m for $15 \mathrm{~min}$ to separate the serum and the serum was stored at $-20^{\circ} \mathrm{C}$ till estimation of sialic acid and uric acid. Both the fasting blood glucose (Glucose oxidase-Peroxidase method) and serum uric acid (modified Trinder method) levels were estimated using VITROS 5600 (fully automated biochemistry analyzer). Serum sialic acid was measured using Ehrlich's reagent in spectrophotometer.

Ehrlich's method of measuring serum sialic acid was based on the method stated by Sydow et al. (1988) [24]. A $400 \mu \mathrm{l}$ of serum was mixed with $1.2 \mathrm{ml}$ of $5 \%$ perchloric acid for $5-10 \mathrm{~min}$ at $100^{\circ} \mathrm{C}$ and centrifuged at $2000 \mathrm{rpm}$ for $5 \mathrm{~min}$. The supernatant $(400 \mu \mathrm{l})$ was mixed with $400 \mu \mathrm{l}$ of Ehrlich reagent ( $5 \mathrm{~g}$ of p-dimethylaminobenzaldehyde $/ 50 \mathrm{ml}$ of $\mathrm{HCl} / 50 \mathrm{ml}$ of distilled water). After incubation at $100^{\circ} \mathrm{C}$ for $15 \mathrm{~min}$, a spectrophotometer was used to read the optical density at $525 \mathrm{~nm}$.

\section{Ethics approval}

The research was carried out after obtaining written consent from the patient and ethical approval from the Institutional Ethical Committee.

\section{Statistically analysis}

Independent sample $t$-test was used to see the mean difference between the two groups for measurement scale data. $p<0.05$ is considered as statistically significant at $95 \%$ confidence level. $p<0.001$ is regarded as highly significant. The statistical software SPSS version 24.0 was used in the analysis.

\section{RESULTS}

The results of various investigations conducted on two study groups are shown in Tables 1 and 2. The results are compared between case and control groups.

\section{Fasting blood glucose}

The mean values of fasting blood glucose of the control group and the case group are shown in Table 1. Highly significant difference is found in the case group when compared to the control group with higher values found in the case group. There is $92.39 \%$ increase in the case group when compared to the control group.

\section{Serum sialic acid}

The mean values of serum sialic acid of the control group and the case group are shown in Table 1 and Fig. 1. Highly significant difference is found in the case group when compared to the control group with higher values found in the case group. There is $93.14 \%$ increase in the case group when compared to the control group.

\section{Serum uric acid}

The mean values of serum uric acid of the control group and the case group are shown in Table 1 and Fig. 2. There is no significant difference found in the case group when compared to the control group with slightly higher values found in the case group, which is non-significant with $\mathrm{p}=0.323$.

Correlation of fasting blood glucose, serum sialic acid, and serum uric acid in the case group

The correlation between fasting blood glucose, serum sialic acid, and serum uric acid in the case group is shown in Table 2.

\section{DISCUSSION}

Much attention has been paid in recent years to the relationship between inflammation and diabetes mellitus. The serum sialic acid was found to be one of the acute-phase markers associated with diabetes mellitus. Blood glucose elevation encourages inflammation by increasing the oxidative stress. Resistance to insulin and hyperglycemia can promote inflammation, which may be a related factor in diabetes development and atherosclerosis [25]. The vascular permeability is regulated by the moiety of sialic acid. The vascular endothelium carries a high amount of sialic acid, so sialic acid is released into circulation when vascular damage occurs [26]. The present research was, therefore, carried out

Table 1: Comparison of mean fasting blood glucose, serum sialic acid, and serum uric acid values between the case and control groups

\begin{tabular}{|c|c|c|c|c|c|c|}
\hline Parameters & Group & $\mathbf{n}$ & Mean & Standard deviation & t-value & p-value \\
\hline \multirow[t]{2}{*}{ Fasting blood glucose (mg/dl) } & Case & 35 & 174.77 & 30.12 & 15.625 & $<0.001$ \\
\hline & Control & 35 & 90.97 & 9.98 & & \\
\hline \multirow[t]{2}{*}{ Serum sialic acid (mg/dl) } & Case & 35 & 76.60 & 7.89 & 17.644 & $<0.001$ \\
\hline & Control & 35 & 39.66 & 9.55 & & \\
\hline \multirow[t]{2}{*}{ Serum uric acid (mg/dl) } & Case & 35 & 4.48 & 0.79 & 0.995 & 0.323 \\
\hline & Control & 35 & 4.28 & 0.89 & & \\
\hline
\end{tabular}

$\mathrm{p}<0.001$ highly significant, $\mathrm{p}<0.05$ significant, and $\mathrm{p}<0.1$ non-significant

Table 2: Correlation between fasting blood glucose, serum sialic acid, and serum uric acid in the case group

\begin{tabular}{llc}
\hline Correlation & Fasting blood glucose & Serum sialic acid \\
\hline Fasting blood glucose (mg/dl) & & $0.941^{* *}$ \\
$\quad$ Pearson correlation & 1 & $<0.001$ \\
$\quad$ Sig. (two tailed) & & 0.148 \\
Serum sialic acid (mg/dl) & $0.941^{* *}$ & 0.396 \\
$\quad$ Pearson correlation & $<0.001$ & 0.156 \\
$\quad$ Sig. (two tailed) & 0.148 & 0.37 \\
Serum uric acid (mg/dl) & 0.396 & 0.156 \\
$\quad$ Pearson correlation & & 1 \\
$\quad$ Sig. (two tailed) & & 0.37 \\
\hline
\end{tabular}

**Correlation is significant at $<0.001$ level (two tailed) 


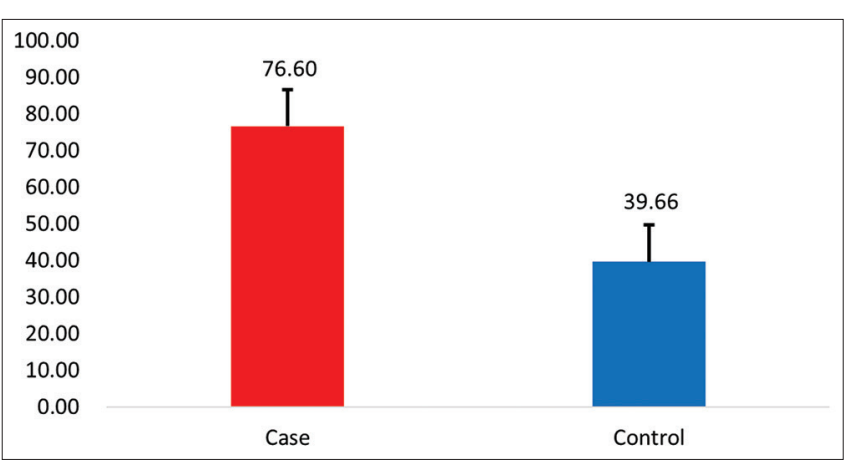

Fig. 1: The mean level of serum sialic acid in the case and control groups. Case: Type-2 diabetes mellitus, control: Non-diabetics

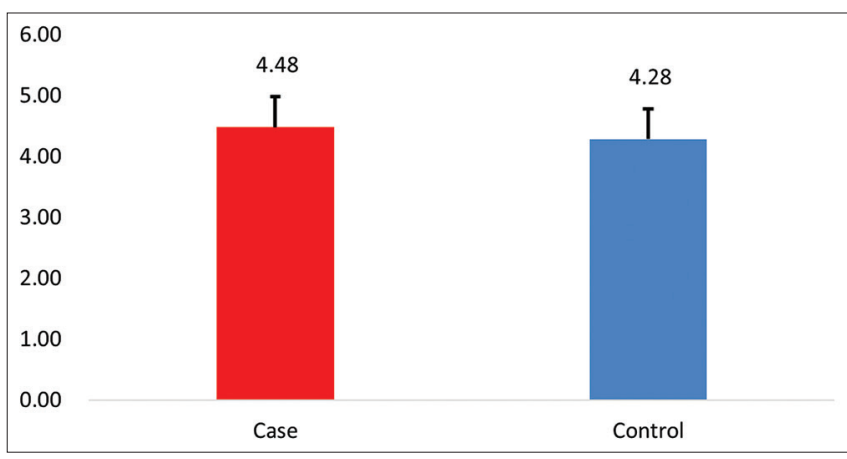

Fig. 2: The mean level of serum uric acid in the case and control groups. Case: Type-2 diabetes mellitus, control: Non-diabetics

to assess the levels of sialic acid in individuals with type- 2 diabetes mellitus and non-diabetics.

As shown in Table 1, the serum sialic acid levels of type-2 diabetes mellitus have been shown to be increased in the present study $(76.60 \pm 7.89)$ when compared to non-diabetics (39.66 \pm 9.55$)$ with a statistically significant, $\mathrm{p}<0.001$. Several researchers have found elevated sialic acid concentration in type- 2 diabetes. The tissue injury caused by vascular complications of the diabetes mellitus activates the local cytokine production from cellular infiltrations. This triggers an acute-phase response which leads to the release of acute-phase glycoproteins from the liver with sialic acid into the bloodstream, resulting in increased concentrations of serum sialic acid [27].

Uric acid, although one of the main antioxidants in circulation, it can cause oxidative stress in a number of cells including vascular smooth muscle cells, mediating on cardiovascular disease progression [28]. The correlation between uric acid levels and diabetes mellitus has been a hot topic of research over the years. The current study was conducted to determine the levels of the serum uric acid in type-2 diabetes mellitus. In our present analysis, serum uric acid levels were found to be increased in type- 2 diabetes mellitus ( $4.48 \pm 0.79)$ when compared to non-diabetics $(4.28 \pm 0.89)$ with a statistically non-significant, $\mathrm{p}=0.323$, as shown in Table 1 .

The causal link between hyperuricemia and type- 2 diabetes can be mediated by both kidney dysfunction and insulin resistance. Nonetheless, not many researchers have reached the same conclusion; a broad prospective study did not show a correlation between uric acid levels and type 2 diabetes, and an inverse association was also found between serum uric acid levels and diabetes mellitus. In type2 diabetes mellitus, hyperuricemia typically results from under excretion of uric acid as a secondary response to hyperinsulinemia. The diabetes condition can also have a direct effect on the oxidation of purine nucleotides, resulting in increased levels of uric acid. In addition, hyperinsulinemia might also lead to hyperuricemia by increasing the xanthine oxidase activity [29]. Uric acid also prevents the bioavailability of nitric oxide, necessary for the absorption of insulin-stimulated glucose. This eventually leads to worsen insulin resistance [30]. However, our study shows an increase in serum uric acid levels in type-2 diabetes mellitus cases but non-significant increase which may be probably due to not having data on variable such as duration of diabetes mellitus in these patients. In future, a long-term study may be conducted by increasing the sample size including the duration of diabetes mellitus to conclude an association between the severity of diabetes mellitus and uric acid levels.

In the present study, serum sialic acid concentration increases with increase in fasting blood glucose concentration in type-2 diabetes patients, which is concomitant with the other studies. However, the results of serum uric acid also show slight elevation in type-2 diabetics when compared to the non-diabetics. Therefore, serum sialic acid and serum uric acid could be considered as an early marker of type- 2 diabetes mellitus.

\section{CONCLUSION}

It is concluded from the present study that serum sialic acid and serum uric acid levels were found to be positively associated with type-2 diabetes mellitus in both men and women, indicating the risk that these patients may develop microvascular complications. Hence, estimating the levels of serum sialic acid and serum uric acid aids in early diagnosis and the prevention of microvascular complications caused by type- 2 diabetes mellitus.

\section{ACKNOWLEDGMENT}

I wish to extend my special thanks to my supervisor, cosupervisor, and all the faculties of the department of biochemistry for their guidance and support in completing my research work.

\section{AUTHORS' CONTRIBUTIONS}

All the above-mentioned authors contributed significantly, directly, and intellectually to the work and authorized it for publication.

\section{CONFLICTS OF INTEREST}

There are no conflicts of interest connected with this article.

\section{REFERENCES}

1. Jain R, Jain P, Jain P. A review on treatment and prevention of diabetes mellitus. Int J Curr Pharm Res 2016;8:16-8.

2. Andayani TM, Izham M, Ibrahim M, Asdie AH. The association of diabetes-related factor and quality of life in Type 2 diabetes mellitus. Int J Pharm Pharm Sci 2010;2:139-45.

3. Rabba AK, Aljiris WS, Ahmed NJ, Alkharfy KM. Medication adherence in Type 2 diabetic patients: A study in Saudi Arabia. Int J Pharm Pharm Sci 2017;9:247-50

4. Prajna K, Kumar JA, Rai S, Shetty SK, Rai T. Predictive value of serum sialic acid in Type-2 diabetes mellitus and its complication (nephropathy). J Clin Diagn Res 2013;7:2435-7.

5. Jafri SA, Rehman KU, IIyas N, Imran AB, Qasim $M$, Zahra $M$. Evaluation of serum sialic acid and other risk factors in diabetes mellitus. Acad J 2017;16:2326-30.

6. Nayak SB, Bhaktha G. Relationship between sialic acid and metabolic variables in Indian Type 2 diabetic patients. Lipids Health Dis 2005;4:1-4.

7. Pickup JC, Mattock MB, Chusney GD, Burt D. NIIDM as disease of the innate immune system: Association of the acute phase reactants and interleukin-6 with metabolic syndrome X. Diabetologia 1997;40:1286-92.

8. Nayak SB, Duncan H, Lallo S, Maraj K, Matmungal V, Matthews F, et al. Correlation of microalbumin and sialic acid with anthropometric variables in Type-2 diabetic patients with and without nephropathy. Vascular Health Risk Management 2008;4:243-7.

9. Pickup JC. Inflammation and activated innate immunity in the pathogenesis of Type 2 diabetes. Diabetes Care 2004;27:813-23.

10. Crook M, Tutt P, Pickup JC. Elevated serum sialic acid concentration in noninsulin dependent diabetes and its relationship to blood pressure and retinopathy. Diabetes Care 1993;16:57-60. 
11. Crook MA, Earle K, Morocutti A, Yip A, Viberti GC, Pickup JC. Serum sialic acid, a risk factor for cardiovascular disease, is increased in IDDM patients with microalbuminuria and clinical proteinuria. Diabetes Care 1994; 17:305-10.

12. Bhole V, Choi JW, Kim SW, Vera de M, Choi H. Serum uric acid levels and the risk of Type 2 diabetes: A prospective study. Am J Med 2010;123:957-61.

13. Talwar T, Tanwar L, Gupta M, Singal KK. Study of serum uric acid levels in Type 2 diabetes mellitus patients. IOSR J Dent Med Sci 2017;16:83-9.

14. Dehghan A, Van Hoek M, Sijbrands EJ, Hofman A, Witteman JC. High serum uric acid as a novel risk factor for Type 2 diabetes. Diabetes Care 2008;31:361-2.

15. Chien KL, Chen MF, Hsu HC, Chang WT, Su TC, Lee YT, et al. Plasma uric acid and the risk of Type 2 diabetes in a Chinese community. Clin Chem 2008;54:310-6.

16. Kramer CK, Von Mühlen D, Jassal SK, Barrett-Connor E. Serum uric acid levels improve prediction of incident Type 2 diabetes in individuals with impaired fasting glucose. The rancho Bernardo study. Diabetes Care 2009;32:1272-3

17. Nakanishi N, Okamoto M, Yoshida H, Matsuo Y, Suzuki K, Tatara K. Serum uric acid and risk for development of hypertension and impaired fasting glucose or Type II diabetes in Japanese male office workers. Eur J Epidemiol 2003;18:523-30.

18. Kodama S, Saito K, Yachi Y, Asumi M, Sugawara A, Totsuka K, et al. Association between serum uric acid and development of Type 2 diabetes. Diabetes Care 2009;32:1737-42.

19. Modan M, Halkin H, Karasik A, Lusky A. Elevated serum uric acid a facet of hyperinsulinaemia. Diabetologia 1987;30:713-8.

20. Taniguchi Y, Hayashi T, Tsumura K, Endo G, Fujii S, Okada K. Serum uric acid and the risk for hypertension and Type 2 diabetes in Japanese men: The Osaka health survey. J Hypertens 2001;19:1209-15.

21. Oda E, Kawai R, Sukumaran V, Watanabe K. Uric acid is positively associated with metabolic syndrome but negatively associated with diabetes in Japanese men. Intern Med 2009;48:1785-91.

22. Nan H, Dong Y, Gao W, Tuomilehto J, Qiao Q. Diabetes associated with a low serum uric acid level in a general Chinese population. Diabetes Res Clin Pract 2007;76:68-74.

23. American Diabetes Association. Classification and diagnosis of diabetes: Standards of medical care in diabetes. Diabetes Care 2019;42:S13-28.

24. Sydow G, Wittmann W, Bender E, Starick E. The sialic acid content of the serum of cattle infected with bovine leukosis virus. Arch Exp Veterinarmed 1988;42:194-7.

25. Ismail SA, Bakeer H, Aziz MM, Fahmy IA, El Hefni M, Nabil S, et al. Role of elevated serum sialic acid in the progression of both diabetic retinopathy and diabetic nephropathy. J Med Sci Clin Res 2015;3:8422-31.

26. Prakash S, Sudha S. Relationship between nitric oxide and sialic acid concentrations in South Indian Type 2 diabetic patients. Adv Appl Sci Res 2013;4:258-62.

27. Ghosh J, Datta S, Pal M. Role of sialic acid in prediction of diabetic nephropathy. AI Ameen J Med Sci 2016;9:58-64.

28. Causevic A, Semiz S, Dzankovic AM, Cico B, Dujic T, Malenica M, et al. Relevance of uric acid in progression of Type 2 diabetes mellitus. Bosnian J Basic Med Sci 2010;10:54-9.

29. Hussain A, Latiwesh OB, Ali F, Younis MY, Alammari JA. Effects of body mass index, glycemic control, and hypoglycemic drugs on serum uric acid levels in Type 2 diabetic patients. Cureus 2018;10:e3158.

30. Rathore A, Samota MK, Bedwal H, Tank L, Jain SC. Serum uric acid and Type 2 diabetes mellitus complications. J Evid Based Med Healthc 2018;5:870-3 